\title{
INDEX
}

Afghanistan

Afghan War,

British treatment of prisoners, 362

course of, 336-337

succession of government, 334-336

US treatment of prisoners, 361-362

Afghanistan-Pakistan diplomatic relations, 345-346

Buddhist statues, demolition of, 343

China-Taleban relations, 343

consular access to detainees in, 344

inter-State relations. See Inter-State relations

Osama bin Laden, refusal to hand over, 354

refugees to Pakistan, 389

sanctions against, 391

Taleban control, 343

Taleban, demand for UN seat by, 400

Arbitration

Bangladesh, legislation in, 167-169

foreign decision, cancellation conditions in South Korea, 197-198

India,

arbitrators, appointment by court, 178-179

New York Convention on Recogni-

tion and Enforcement of

Foreign Arbitral Awards, inter-

pretation of, 175-178

participation in treaties, 266

Armed force

humanitarian intervention, after World War II, 103-106

before World War II, 98-103

Catholic minorities, protection of, 107

Cuba, in, 101

doctrine, place of, 97 ethical obligation, as, 114-117

higher ranking law, under 111-117

human rights, protection of, 106-119

Iraq, in, 96-97, 99, 121

justification by, 96-97

Kosovo, in, 113-114

Lebanon and Damascus, in support of

Christian minorities in, 101

legal right, as, 102

legality of, 112

legitimacy and validity of, 121-122

lives at stake, where, 111

mass violations of human rights, on event of, 123

place of, controversy as to, 105-106

political independence, against, 118

regional organizations, by, 124

secular standpoint, from, 99

sovereignty, violation of, 100

State practice, 119-121

status of, 102

Suez crisis, in, 112-113

territorial integrity of states, against,

118-119

treaties, under, 107-108

Turks, in aid of Greek insurgence

against, 100

UN Charter Article 2(4), under, 117119

NATO action, goals of, 97

non-intervention, principle of, 104-105

non-use, principle of, 104-105

prohibition on use of, 95

self-defence, as, 95, 122-123

unilateral intervention, human rights as pretext for, 117

unilateral military action, 96

United Nations Charter, under, 95 
Armed forces

military manuals, 137

Asia-Pacific Economic Forum (APEC)

annual meeting 2000, 338

summit meeting 2001, 339

Asia Pacific Forum for National Human

Rights Institutions

role of, 53

Asian Development Bank

North Korea, membership issue, 339

Asian-African Legal Consultative Organization

administrative matters, 295

communications received by,

Japan, practice on sovereign immunity, 302-304

Myanmar, State-owned Economic

Enterprises Law, 305-307

state practice of Botswana in relation

to jurisdictional immunities of states, 301

establishment of, 293

Fortieth Session, officers of, 294

headquarters, 293

inter-sessional meetings, 294

matters of common concern having legal implications,

International Criminal Court, work on, 297

international trade law matters, 298

UN Conference on Environment and Development, 298

Member States, matters referred by, international terrorism, 297, 308-319 jurisdictional immunities of States, 297

law of the sea, 295-296

migrant workers, legal protection of, 296

Palestinians, Israeli practices concerning, 296

refugees, status and treatment of, 296 sanctions, extra-territorial application of national legislation, 297

trafficking in women and children, co-operation against, 297, 318-329

membership and organization, 294 questions under consideration by International Law Commission, 295

refugees,

burden sharing, 300

compensation, right to, 299-300

comprehensive solutions, international cooperation on, 299

international organizations, cooperation with, 301

obligations, 301

rights granted, 301

status and treatment of, 296

voluntary repatriation, 298

subjects dealt with, 295

trafficking in women and children, cooperation against, 297

background, 318-319

existing legal framework, 322-328

Indonesia, problem in, 320

meaning, 321

Secretariat, background note by, 320329

subjects of, 321-322

Association of South East Asian Nations (ASEAN)

ASEAN + 3, 340

Declaration on Joint Action to Counter Terrorism, 341

European Union, relations with, 341

Fourth Informal Summit, 340

Free Trade Area, 340

Regional Forum, composition of, 339

Seventh Summit Meeting, 341

Aviation

Indonesia, legislation in, 186

Warsaw Convention, application in

South Korea, 196-197

Bangladesh

arbitration legislation, 167-169

India, border dispute, 342

Mynamar, border dispute, 342

Borders

Bangladesh-India, 342

Bangladesh-Myanmar, 342

Myanmar-Thailand, 342 
Cambodia

Khmer Rouge leaders, trial of, 357-358

Thailand, Memorandum of Understanding as to area of overlapping claims to continental shelf, 253-255

Caste system

Dalits, 39-43

discrimination based on, 39-44

economic phenomenon, as, 42

human rights provisions, 43-44

identity, 40

India, legal framework in, 42-43

origins and definition, 40

scope of, 40

untouchability, notion of, 41

China, People's Republic of aircraft, bugging, 353

chairman of National People's Congress of China, immunity from service of court summons, 344

China-Taleban relations, 343

cross-Strait talks, appeal for, 348

export of missiles, restrictions on, 382383

inter-State relations. See Inter-State relations

Israeli export of dual-use technology to, US embargo on, 352

Korea, four-party talks on, 350

Sino-Japanese tariffs dispute, 404 softening of policy to Taiwan, 350

Taiwan, mainland links, 348

Taiwanese investments in, 349

terrorism, 399

trade union, interpretation of treaty obligation, 357

US military co-operation, 382

US withdrawal from ABM Treaty, response to, 347

World Trade Organization, membership of, 402-403

Comprehensive Nuclear Test Ban Treaty, 289

Convention Against Torture and other Cruel, Inhuman or Degrading Treatment or Punishment, 274

Convention on International Trade in Wild Flora and Fauna (CITES) appendices, 75-76

committee, decisions of, 78

Malaysia, compliance in,

actions for, 77

co-operation system, 79-80

environmental awareness, lack of, 8283

expertise, lack of, 78-80

laws and institutions for, 76-77

legislation, weakness in, 80-81

penalties, 81

problems with, $78-83$

resources, lack of, 82

Scientific Authority, 77, 79

training, 80,82

permits, 76

scope of, 75

Convention on the Control of Trans-

boundary Movements of Hazardous

Wastes and their Disposal (Basel

Convention)

implementation, mechanism for, 84-85

main principles of, 84

Malaysia, compliance in, 87-88

laws for, 85

participation in, 270-271

scope of, 83

Convention on the Elimination of All

Forms of Discrimination against

Women, 274-275, 323-324

Convention on the Nationality of

Married Women, 274

Convention on the Political Rights of

Women, 273

Convention on the Prevention and

Punishment of Genocide

adoption of, 29

Convention on the Rights of the Child,

275, 324-325

adoption of, 30

status of, 31

Crimes

individual criminal responsibility, principle of, 136

international,

East Timor, UN indictments for, 358

Khmer Rouge leaders, trial of, 357-

358 
participation in treaties, 276-279

international law, in, 128

peace and security of mankind, against, 136

Cultural matters

Buddhist statues, demolition in

Afghanistan, 343

participation in treaties, 266

Cultural property

participation in treaties, 267

Currency

Asian currency safety net, 385

Customary law

acquisition of status of, 132-133

Geneva Conventions Common Article

3 as, 131, 134

universal permissive jurisdiction, as

basis for application of, 143

Danav River

dam project, 390

Democracy

Iran president, speech by, 343

Development

participation in treaties, 269

Diplomatic and consular functions

Afghanistan, consular access to detainees in, 344

Diplomatic and consular immunity and inviolability

foreign consulates, refuge in, 344-345

National People's Congress of China, immunity of chairman from service of court summons, 344

Diplomatic and consular relations

Afghanistan-Pakistan, 345

Iran-United Kingdom, 346

North Korea, in, 346

Disarmament

US withdrawal from ABM Treaty,

Chinese response to, 347

Discrimination

Iranian Jews, espionage trial of, 347

Dispute settlement

participation in treaties, 268

Dissidents

Myanmar, in, 347-348
East Timor

crimes,

Indonesian trials, 358

UN indictments, 358

independence, 392

oil and gas fields, revenue-sharing with Australia, 387

UN Transitional Administration, alleged racial bias, 400

Embargoes

arms sales to Iran, renunciation of US-

Russia agreement on, 352

Indonesia, US arms embargo against, 352

Israeli export of dual-use technology to China, US embargo on, 352

Environment

Caspian Sea, fishing in, 353

flora and fauna, 268-272

Kyoto Protocol, Japanese disavowal and later ratification of, 353

participation in treaties, 268-272

whaling, 352

Espionage

Chinese aircraft, bugging, 353

European Union

ASEAN, relations with, 341

expansion of, 163-164

trade barriers, phase-out of, 360

Extradition

India, from, 173-175

Philippines-China Treaty, 231

Philippines, right of extraditee to bail, 210-211

South Korea, procedure in, 198-199

Thailand, judicial decision in, 249-252

Family

participation in treaties, 273

Finance

participation in treaties, 273

Foreign investment

Iranian legislation, 353

Genocide

Convention, 29 


\section{Great Britain}

Anglo-Japanese Agreement, 1905, conclusion of, 13-18

extension of, 15

Korea, place of, 14-18

Koreans, impact on, 11

negotiation, history of, 14

other powers, presentation of policy to, 16

Korea, Treaty of Friendship and Commerce with, 19

Health

participation in treaties, 273

Hong Kong

Philippines, treaty on mutual assistance with, 231-232

Human rights

accountability, 28

armed intervention for protection of, 106-119. See also Armed force

Cold War, impact of, 29

implementation of conventions, 31

Indonesia, legislation in, 188-189

International Bill of Rights, 30

international law, 28-31

life, right to, 34-39

mass violations, unacceptable, 116

misuse of, prevention of, 115

modern movement, origins of, 27

participation in treaties, 273-275

South Asia, in,

Ahmadiyya Muslim community, against, 44-48

Bangkok Declaration, 27

caste-based discrimination, 39-44

constitutional and legislative protection, 26

cooperation, fora for, 53

current issues, 31-48

current situation, identification of, 25

democracy, 33-39

detained persons, 35-36

development, right to, 32-33

economic deprivation, 36

education, 36-37

gender discrimination, 37-39

globalization, effect of, 32-33 governance, 33-39

international law, 27-31

judiciary, responsibility of, 34-35

life, right to, 34-39

mass killings, 34-35

poverty, 32-33, 36-37

reality of, 25-26

record on, 55

religious minorities, against, $44-48$

Rome Statute, ratification of, 29

rule of law, 33-39

sub-regional system, 52-55

specific individuals, for, 28

stability and peace, link with, 48

UN Charter provisions, nature of 109-

111

unilateral armed intervention, as pre-

text for, 117

United Nations, debate in, 108-109

universal nature of, 27

war, violations during, 28

India

arbitration,

arbitrators, appointment by court,

178-179

New York Convention on Recognition and Enforcement of Foreign

Arbitral Awards, interpretation of, 175-178

caste-based discrimination, 39-44

extradition from, 173-175

maritime liens, judicial decision on,

170-171

tribals, displacement and rehabilitation of, 171-173

Indonesia

air law, 186

anti-terrorism law, 181-186

crimes against humanity, jurisdiction, 180

human rights law, 188-189

law of the sea, $187-188$

space law, 186-187

trafficking in women and children, problem of, 320

Intellectual property

participation in treaties, $275-276$ 
International Convention on the Elimination of All Forms of Discrimination against Women

adoption of, 30

International Convention on the Elimination of All Forms of Racial Discrimination,

adoption of, 30

caste system, and, 43-44

International Convention on the Protection of the Rights of All Migrant Workers and Members of Their Families, 274

adoption of, 30

International Covenant on Civil and Political Rights 29

International Covenant on Economic, Social and Cultural Rights, 29, 274

International Criminal Court establishment of, 141 jurisdiction, 28, 142 purpose of, 136

Rome Statute, 28-29 role in criminalization of Common

Article 3, 141-143

International law basic principles of, 104 compliance. See Treaties Nepal, inception and adoption in, 155156

self-interest governing, 58-59

State will, as reflection of, 57

International Law Commission international law, development of, 136 legal doctrines, forming, 136

International representation participation in treaties, 279

International trade participation in treaties, 279

International Tribunal for Rwanda conflict, nature of, 135 internal conflicts, development of law of, 134-135

International Tribunal for the Former Yugoslavia

draft statute, 133-135

internal conflicts, development of law of, 134-135 international nature of conflict, 135

violations of law dealt with, 135

Japan

Anglo-Japanese Agreement, 1905, conclusion of, 13-18

extension of, 15

Korea, place of, 14-18

Koreans, impact on, 11

negotiation, history of, 14

other powers, presentation of policy to, 16

child born out of wedlock, discrimination against, 190-193

Korea, seizure of. See Korea

Nauru, sovereign immunity from civil law jurisdiction, 193-194

practice on sovereign immunity, 302304

territorial sea, judicial decision on delimitation of, 189-190

Judicial and administrative cooperation participation in treaties, 280

Jurisdiction

derivation of powers, 126-127

enforcement, 126

meanings of, 126

prescribe, power to, 126

territoriality, principle of, 127

universal,

assessment of theories of, 128

circumstances in which applied, 132

concept of, 125, 127-128

domestic legislation, 137-139

forms of, 129-130

mandatory and permissive, 129

scope of, 127-128

Korea

Anglo-Japanese Agreement, 1905, impact of, 11, 15-18

Britain, Treaty of Friendship and Commerce with, 19

British interests in, 20

independent state, survival as, 23-24

Japanese seizure of,

Advisers, appointment of, 7-8

annexation, $18-22$ 
archival record, chronology of, 4

Bonar, reports of, 18-22

Britain and Egypt compared, 10

Britain, knowledge of, 22-23

British interests, effect on, 20

criticism of conduct in, 9

currency and financial agreements, 9

Customs Administration, assumption

of control over, 11

first treaty encroachments, 5-7

grip, tightening, 7-8

international context, in, 4

international law, character of, 4

invalidity, 22

Jordan, reports by, 4-13

legality of presence in, 12

other States, role of, 4

Protectorate, imposition of, 9-13

reforms, introduction of, 10

representation abroad, 9

tensions, causing, 3

treaties, 3

execution of, 19

misgovernment of, 6

organizational capacity, 5

Labour

participation in treaties, 280-281

Malaysia

anti-personnel mines, implementation of Convention, 204-205

Basel Convention, problems of compliance with, 87-88

CITES, compliance with. See Convention on International Trade in Wild Flora and Fauna (CITES)

fishery regulations, 81

foreign judgment, enforcement of, 200202

hazardous wastes, import and export of, 85-87

Pulau Ligitan and Pulau Sipadan, sovereignty over, 202-204

Ramsar Convention, compliance with, 88-90

Mekong River

navigation, 390
Military alliance

Asia-Pacific, 381

Military cooperation

China-US, 382

India-US, 382

Indonesia-US, 382

Philippine-US, 381

Missile technology

China, restrictions on export from, 382-383

Iran, 383

Israel, 383

North Korea, 383-384

South Korea, 384

Myanmar

Bangladesh, border dispute, 342

dissidents, 347-348

ILO sanctions against, 392

inter-State relations. See Inter-State relations

nuclear energy, 385

refugees from, 389

State-owned Economic Enterprises Law, 305-307

Thailand, border dispute, 342

Narcotic drugs

participation in treaties, 282

Nationality and statelessness

participation in treaties, 282

Nepal

clean drinking water, right to, 207-208

Constitution, 148

foreign investments in, 154

human rights conventions signed by, 153

ILO conventions signed by, 153

insurgents, 357

international commitments, fulfilling, 162

international community, responsibilities to, 159

international law, inception and adoption of, 155-156

law, treaties becoming, 148

legal system, liberalization of, 152-154

monism, adoption of, 155,163 
non-governmental organization on rights of the child, registration of, 205-207

trade, volume of, 154

World Trade Organization, membership of,

amendment of laws, 150-151

constitutional and democratic perspective, 151-152

effort to obtain, 147

final legal arrangements by, 159-161

historical perspective, 148-150

issues, 150-151

legal system, and, 152-154

parliamentary democracy, in context of, 148

post-ratification talks, 163

proposal for, 147

ratification of accession, 152 laws applicable in, 156-158

welfare of people, concerning, 160

North Korea

agreements with South Korea, 351

Asian Development Bank, application for membership, 339

axis of evil, classification as forming part of, 399

diplomatic and consular relations in, 346

family reunions, 350

foreign consulates, refuge in, 344-345

inter-State relations. See Inter-State relations

missile technology, 383-384

nuclear energy,

Korean Peninsula Energy Development Organization, 386

Kumchangri complex, 385

Nuclear energy

Iran-Russia assistance, 385

Korean Peninsula Energy Development Organization, 386

Myanmar, 385

North Korea,

Korean Peninsula Energy Development Organization, 386

Kumchangri complex, 385
Nuclear material

participation in treaties, 283

Oil and gas

East Timor-Australia, revenue-sharing, 387

Oil pollution

participation in treaties, 268-269, 271

treaty compliance, 59

Organization of the Islamic Conference terrorism, position on, 387-388

Outer space

Indonesia, legislation in, 186-187

participation in treaties, 283-284

Pakistan

Afghan refugees to, 389

Afghanistan-Pakistan diplomatic relations, 345-346

Ahmadiyya Muslim community in, 4448

foreign court, execution and enforcement of decrees of, 208-210

inter-State relations. See Inter-State relations

non-Muslims, constitutional definition of, 47

Objectives Resolution, 46

population, 46

religious minorities, discrimination against, $47-48$

suspect in murder, handing over, 354

Taleban and Al Qaeda fighters, handing over, 354

Philippines

bail, right of extraditee to, 210-211

China, extradition treaty with, 231

citizenship legislation, 226-230

Hong Kong, treaty on mutual assistance with, 231-232

insurgents, 356

joint RP-US war exercises, constitutionality of, 212-217

kidnappings in, 337

money laundering legislation, 222-224

Plant Varieties Protection Act, 218-222 
Technical Co-operation Agreement with Germany, legal status of, 217218

US military co-operation, 381 wildlife resources and habitats, protection of, 224-226

Piracy

Asian waters, attacks in, 388

Privileges and immunities participation in treaties, 284

Ramsar Convention on Wetlands of International Importance Especially as Waterfowl Habitat

Malaysia, compliance in, 88-90

obligations of, 88

participation in, 269-270

Tasek Bera site, 88-89

Refugees

Afghan, 389

Asian-African Legal Consultative

Organization, work of, 296, 298-301

Myanmar, from, 389

participation in treaties, 284

South Korea, recognition of status in, 195-196

Tajikistan law, 246

Regional security

anti-missile defence system, plans for, 389-390

US naval unit, visit of, 390

Road traffic and transport

participation in treaties, 284

Russia

inter-State relations. See Inter-State relations

\section{Sanctions}

Afghanistan, against, 391

Myanmar, against, 392

US, data on, 391

Sea

Indonesia, legislation in, 187-188

participation in treaties, 285

Sea traffic and transport

participation in treaties, $285-286$

Singapore

land reclamation, 395
Single Convention on Narcotic Drugs, 282

Social matters

participation in treaties, 286-287

South Asia

human rights. See Human rights

instability, 49

South Asia Forum for Human Rights

role of, 54

South Asian Association for Regional

Cooperation (SAARC)

background, 49-50

establishment of, 51

impact, assessment of, 52

Regional Convention on the

Suppression of Terrorism, 51-52

role and remit of, 50-51

South Korea

agreements with North Korea, 351

extradition procedure, 198-199

family reunions, 350

foreign arbitration decision, cancellation conditions for, 197-198

inter-State relations. See Inter-State relations

missile plans, 384

reduced US military exercise, 351

refugee status, judicial decision on recognition of, 195-196

Warsaw Convention, application of, 196-197

Sri Lanka

civil war, 355

criminal matters, mutual assistance in, 237-239

election, unlawful poll at, 232-234

international child abduction legislation, 234-235

migrant workers, voting rights of, 239

United Nations Regulations, 236-237

State liability

US court verdicts against Iran, 394

State practice

establishment of, domestic legislation, 137-139

judicial decisions, 139-141

military manuals, 137

opinio juris, confirmation of, 137 
State sovereignty

principle of, 57

superior legal order, 58

Sturgeon

Caspian Sea, fishing in, 353

Taiwan

Chinese policy towards, softening of, 350

cross-Strait talks, appeal for, 348

direct investments in China, 349

mainland links, 348

UN seat, proposal for, 349

weapons, request for, 348-349

World Trade Organization, membership of, 403

Tajikistan

cassational appeals, 240-242

criminal law, humanization of, 249

cultural valuables, law on import and export of, 243-244

electronic documents, law on, 247

information protection, law on, 247

informational demands, law on, 245246

Red Cross and Red Crescent emblems, use of, 243

refugees, law on status of, 246

Telecommunications participation in treaties, $287-288$

Terrorism

AALCO Secretariat Study, 309-316

ASEAN Declaration on Joint Action to

Counter, 341

Asian-African Legal Consultative

Organization, work of, 297, 308-319

axis of evil, classification of, 399

China, unrest in, 399

definition, 52

draft comprehensive Convention, 308319

Indonesia, legislation in, 181-186

international and regional instruments related to prevention and

suppression of, 317-318

Organization of the Islamic Conference, position of, 387-388
Regional Convention on the Suppression of Terrorism, 51-52

Thailand, law in, 256-263

US war on, 395-399

Thailand

Cambodia, Memorandum of Understanding as to area of overlapping claims to continental shelf, 253-255

extradition, political offence exception, 249-252

foreign embassy personnel, summons

to appear as witness, 252-253

inter-State relations. See Inter-State relations

international terrorism law, 256-263

Mynamar, border dispute, 342

Treaties

annexation, effect of, 19-20

authoritative interpretation, 73

changes in, 73-74

compliance,

actions encouraging, 73-75

capacity building, 73

cynicism about, 57-60

definition, 61-63

effectiveness and enforcement distinguished, 63-64

evaluating, 62

factors inducing, 65-66

habit of, 90

human factor, 92

ideal, as, 57

implementation, and, 61

implementing action as, 63

information system, 68, 70-72

interdependent self-interest, due to, 67

lack of intention of, 67

non-compliance response system, 68 , $72-73$

non-governmental bodies, participation of, 71

poor, 91

primary rule system, $68-70$

reasons for, 64-68, 91-92

substantial, 62

support for theory, 90-91 
system of management, through, 6875

transparency, 70, 91-92

treaty-making process, consideration of, 65

design, 74

dispute settlement, 72-73

enforcement, 64

implementation, 61

non-compliance,

action in face of, 67-68

effect of, 66

reasons for, 67, 91-92

response system, $68,72-73$

participation in treaties, 288

party losing independent existence,

effect of, 18-19

publicity, 66

sound reporting mechanism, 91

successful, characteristics of, 92

Vienna Convention, 288

voluntary and consensual nature of, 60

United Kingdom

Iran-United Kingdom diplomatic relations, 346

United Nations

Afghanistan, sanctions against, 391

aims of, 104

armed force, use of. See Armed force

Charter, 95, 104, 109-111

protection of human rights, debating, 108-109

seat for Taiwan, proposal for, 349

Security Council,

Japan, candidacy for permanent seat, 400

Taleban, demand for seat by, 400

United States

Central Asia, presence in, 342

criminal suspects, policy as to handover of, 354

foreign steel, tariffs on, 404

inter-State relations. See Inter-State relations theory, 60-75

Vietnam-US trade agreement, 359

Uzbekistan

insurgents, 357

Vietnam

Vietnam-US trade agreement, 359

War

conflicts, number of, 125

criminalization of acts in, 138

Geneva Conventions Common Article 3 ,

binding nature of, 131

criminalization, 132-143

customary international law, as, 131, 134

international human rights provisions, overlap with, 132

minimum provisions, 130

non-international armed conflicts, law of, 125

humanitarian law, treaties, 275

internal conflicts,

criminalization, 134

development of law applicable to, 134-135

domestic law, violations under, 131132

opinio juris, sources of, 133-136

regulation of, 131

state practice, establishment of, 137141

violations of law, 126

law of internal conflicts, violations of, 130

non-international, protection of victims of, 125

state practice, establishment of, domestic legislation, 137-139

judicial decisions, 139-141

military manuals, 137

opinio juris, confirmation of, 137

victims, protection of, 125

War crimes

definition, 137

domestic legislation, 137-139

military cooperation. See Military cooperation international armed conflict, in

sanctions, data on, 391 situations of, 133 
International Criminal Court, jurisdiction of, 142

judicial decisions, 139-141

Weapons

participation in treaties, $288-290$

West Timor

UN workers, murder of, 338

Whaling

Convention, 59

Japan, by, 352

World Bank

anti-poverty project, rejection of, 400

World Trade Organization

accession, legal regime, 157

China, membership of, 402-403

Doha meeting, Asian attitudes to, 403
Doha Round of global trade talks, 404

foreign steel, US tariffs on, 404

Nepal, membership of, 147-164. See also Nepal

ratification and accession laws, 158 absence of parliament, in, 159

Sino-Japanese tariffs dispute, 404

Taiwan, membership of, 403

withdrawal from membership, 157

World War II

comfort women and slave workers, law suit by, 401

comfort women, compensation for, 402

germ warfare, 360

Japan, settlements in, 401

Japanese court, claims rejected by, 401-402 